Revista Iberoamericana, Vol. LXXVI, Núm. 232-233, Julio-Diciembre 2010, 671-693

\title{
ESPÍAS Y DETECTIVES CALIBÁNICOS: MARCANDO Y DIFUMINANDO LOS LÍMITES DE LA NACIÓN CUBANA REVOLUCIONARIA
}

\author{
POR \\ Magdalena LÓPEZ \\ Universidad de Lisboa
}

\begin{abstract}
(los espías y fantasmas) persisten porque están hechos de miedos esenciales. Para seguir vivos tienen suficiente con alguna frontera. Nuestra facultad de entender peligrosa toda lateralidad, nuestras sospechas cifradas al otro lado de cualquier límite, nos harán suponer nuevos fantasmas y nuevos agentes secretos.
\end{abstract}

Antonio José Ponte

Como ningún otro género, las novelas policiales y de contraespionaje cubanas que surgieron durante los años setenta y gran parte de la década siguiente, constituyeron una popular expresión literaria de la propuesta de Roberto Fernández Retamar en su Calibán de 1971. Formulado desde una conciencia periférica, el conocido ensayo abogaba por la “deglución” cultural de Occidente con fines emancipadores. En sintonía con Fernández Retamar, la mayoría de los autores de la isla entendieron la reapropiación del género policial como una operación revolucionaria.

El contexto del auge de la industria editorial y de la tecnificación policial en Cuba, pareció favorable al surgimiento de estas novelas que ya se venían produciendo en otros lugares de América latina ${ }^{1}$ (Nogueras y Rodríguez Rivera 150). La apropiación de esta matriz metropolitana fue sin duda problemática. Centralizadas las políticas culturales, estas novelas pretendieron disciplinar un nuevo sujeto revolucionario cubano en un

1 En efecto, a pesar de que el género en Cuba contaba con pocos precedentes como los de algunos relatos de Lino Novás Calvo y la novela colectiva por entregas "Fantoches" aparecida en la revista Social a lo largo de 1926; esta literatura ya había tenido mayor difusión en Argentina, México y Brasil a lo largo del siglo xx. Amelia Simpson menciona tempranas manifestaciones del género, bien de producción local, bien traducciones en ediciones populares desde finales del siglo xIx en Argentina (9). Escritores, editores y traductores como Carlos Olivera, Paul Groussac, Jorge Luis Borges, Adolfo Bioy Casares y Rodolfo Walsh en Argentina; Coelho Neto, Afrânio Peixoto, Viriato Correi, Jerônimo Monteiro y Luis Lopes Coelho en Brasil; Pepe Martínez de la Vega, Antonio Helú, Rafael Bernal y Rodolfo Usigli en México; dan cuenta de la presencia que tuvo el género policial con anterioridad a los años setenta fuera de Cuba. 
campo discursivo masculinista de acuerdo con los imaginarios totalizadores de la guerra fría. Así, repitieron la paradoja de Calibán al apelar a una identidad originaria en una lógica antitética -hegeliana o marxista- en la que la propia identidad se originaba por oposición a la alteridad dominante. El reciclaje del género literario dramatizó la misma contradicción del esclavo rebelde, quien para lograr su liberación precisaba del lenguaje del amo para revertirlo a su favor. La extensa producción de estas narraciones, su popularidad, así como su irregular calidad literaria, ponen en cuestión los alcances y límites de esta reformulación.

El género policial tuvo su origen con la modernidad decimonónica británica y norteamericana. Como tal, constituye una expresión de la nueva cultura de masas emergente gracias al desarrollo del mercado de consumo capitalista. Conocida también como novela inductiva, del enigma, whodunit (Todorov) o puzzle novel, se considera generalmente un género conservador destinado a reafirmar los valores liberales dominantes de la época (Simpson 11). La feliz resolución del crimen, esto es, la confiabilidad del sistema, vino garantizada por el campo emergente de las ciencias modernas, sustentadas en la infalibilidad de la razón como el instrumento cognoscitivo por excelencia. La novela policial, como las novelas de aventuras, diarios de viaje y demás géneros que florecieron simultáneamente, emergieron en un contexto en el que la ciencia moderna proveía los imaginarios culturales necesarios para aprehender a los "otros": el criminal, la prostituta, el exótico colonializado, entre otros. Como representante de un orden hegemónico, el detective restaura un orden momentáneamente roto al descubrir a ese “otro" delincuente. De ese modo, el género policial clásico sugiere los límites del adentro y del afuera, construye alteridades. Para Julio Miranda

Somos el decorado exótico de los crímenes de Agatha Cristie, somos los criados de ojos rasgados, las bailarinas fogosas que sirven de cebo para atrapar ingenuos blancos; somos el detective más despreciado de todo el género policial: Charlie Chan [...] Los ojos de la viejísima y asustadísima Agatha [...] son en verdad, los ojos del imperio (en Braham 4-5)

En la Cuba revolucionaria, la producción de novelas policiales implicaría revertir esa mirada imperial, hacer de Charlie Chan no el estereotipo colonial sino una amenaza anticolonialista. Como sucedía con la apropiación del lenguaje de Próspero, retomar el género literario se propone como una hazaña calibánica. Auspiciadas desde 1971 por el Ministerio de Interior (MININT) a través de concursos anuales, estas novelas buscaron delimitar los campos de los "arieles” y los “calibanes" de la revolución en un género literario que paradójicamente era connatural al mundo capitalista tan crudamente expuesto ya no en las cándidas novelas victorianas sino en las novelas negras norteamericanas de entreguerras. Si Dashiel Hammet y Raymond Chandler actualizaron la mirada confiada y celebratoria del detective por una de desencanto, todos los detectives literarios antes

Revista Iberoamericana, Vol. LXXVI, Núms. 232-233 Julio-Diciembre 2010,
ISSN 0034-9631 (Impreso) 
y después de esta renovación norteamericana compartían sin embargo, la mirada del sujeto individual de las sociedades capitalistas.

La escritura desde un socialismo periférico de las novelas policiales pretendió como Calibán, reclamar una originalidad cubana sobre una narrativa condenada a su decadencia en los países originarios: "la novela policial cubana surge, indudablemente como el fruto de la asimilación de lo mejor de la novela policial clásica, pero también como reacción contra la decadencia de la escuela inductiva y la degeneración de la escuela dura” (Nogueras y Rodríguez Rivera 152).

Resalta en esta cita, el uso en el lenguaje de Luis Rogelio Nogueras y Guillermo Rodríguez Rivera de términos como “degeneración” y “decadencia” que remiten paradójicamente a la misma jerga positivista con la que Occidente configuró a sus otros. Su afirmación delata la problemática del reciclaje: una absorción en la que se conservan los supuestos cientificistas dominantes. Estos supuestos revelan hasta qué punto las expresiones culturales revolucionarias se teorizaban desde una concepción lineal y progresiva de la historia. Como ya quedaba sugerido años antes en la obra del mismo Alejo Carpentier, los imaginarios nacionales entrañaron la promesa de una civilización fresca y vital, que habría de suceder a la hegemónica en decadencia. Es en esta misma dirección que José Antonio Portuondo realza la novela policial cubana y la soviética:

la novela contemporánea sufre una anemia profunda, de una absoluta falta de sangre
que autores como Joyce han pretendido sustituir con las más repugnantes purulencias
y otros, como Virginia Wolf, por algún heredero de aquel misterioso súco nérveo que
Doña Oliva Sabuco, en el siglo xvi, creía responsable de los fenómenos vitales. La
sangre desborda entre tanto, en las páginas de las novelas detectivescas donde el hombre
vuelve a encontrarse con la muerte (78)

La legitimación del género en Cuba frente a sus modelos "originales” emuló cierta lógica rodosiana al identificar las vanguardias estéticas con la "degeneración" (Braham 27). Ciertamente el nuevo héroe detectivesco debía como Calibán, representar un modelo de juventud, moralidad, salud y virilidad. Todas estas virtudes a su vez, aparecían estrechamente relacionadas a una violencia purificadora como la sostenida por Franz Fanon. La sangre desbordante no sólo refería entonces vitalidad sino también, una concepción de la violencia que, como en el ensayo de Fernández Retamar, dotaba de agencia a una identidad subalternizada: "En Calibán los tiempos de la confrontación política o armada son los momentos privilegiados que certifican la presencia del ser cultural latinoamericano” (Quintero 73). Como el lenguaje del amo, la experiencia colonial en tanto violencia constitutiva, proveería también las herramientas para la emancipación. El detective como expresión del hombre nuevo, debía por tanto ajustarse a los preceptos culturales beligerantes que empezaron a regir a partir del Primer Congreso de Educación y Cultura de 1971:

Revista Iberoamericana, Vol. LXXVI, Núms. 232-233 Julio-Diciembre 2010, 671-693
ISSN 0034-9631 (Impreso) 
el arte es una rama de la revolución. Un producto de la moral combativa denuestro pueblo. Un instrumento contra la penetración del enemigo [...] Nuestro arte y literatura serán un valioso medio para la formación de la juventud dentro de la moral revolucionaria, que excluye el egoísmo y las aberraciones típicas de al cultura burguesa. (en Esteso 23)

El género policial serviría de correctivo frente a una erudición vanguardista asociada con las “aberraciones” de la intelectualidad burguesa decadente (Braham 4). El problema básico, era que el género se alimentaba precisamente de la sordidez que la misma revolución decía desterrar. Esta contradicción fue percibida en algunos escritores del género como Luis Rogelio Nogueras. En el libro de ensayos Por la novela policial, Nogueras resalta negativamente los orígenes históricos del género coincidentes con el apogeo de una "deleznable” revolución industrial (13-14). La literatura de masas, adolecía, por así decirlo, del pecado original de haber nacido de la ideología dominante del xix. Nogueras insiste en que se trataba de "un género que, en muchos casos -en sus vertientes más espurias- sirvió y sirve para embrutecer a las masas y alejarlas de los verdaderos problemas sociales y políticos mediante el opio de la evasión” (36). Al igual que los mismos intelectuales al momento de la revolución, el género debía expiar la culpa de sus orígenes, debía ser disciplinado. La posibilidad de revertir una literatura capitalista de "evasión" por una de moralización revolucionaria evoca las potencialidades que Walter Benjamín veía en el cine y en general en el arte moderno. Al ser reproducidos técnicamente, los objetos lograrían desplazarse del dominio de la tradición, de lo ritual, a lo político. (“work” 5). Para Benjamín, la pérdida del aura, de la unicidad del objeto, permitía un acercamiento entre las masas y la obra de arte en la que la experiencia estética actuaba de manera dual: bien en la perpetuación de valores conservadores, como en efecto Nogueras juzga a la literatura policial clásica, o bien en la trasformación política de la sociedad. Esto último supondría lo contrario de una estetización de la política ("work” 4): la politización del arte propia del comunismo (“work" 15).

La exigencia de la parametrización de los funcionarios, artistas y educadores vinculados a la cultura respondió sin duda a la necesidad de supeditar el arte y la cultura a los imperativos de la política del llamado "quinquenio gris", hubo pues, una politización dirigista y oficialista del arte. Pero no fue una politización orgánica sino disciplinaria. La novela policial de la revolución pareció desterrar toda problemática presente para abocarse a un orden utópico futurista siguiendo una lógica similar a la de Che en el "El socialismo y el hombre nuevo en Cuba" al desvalorizar a los intelectuales y artistas cubanos en función de un hombre nuevo que habría de sustituirlos. Como la imagen guevariana del olmo al que se le injertan peras para referirse a los intelectuales; la reformulación del género policial en Cuba resultó una suerte de producto híbrido que no rindió muchos frutos, agotándose en la repetición de estrictas fórmulas. Tal disciplinamiento revolucionario coaccionó las potencialidades de una narrativa policial

Revista Iberoamericana, Vol. LXXVI, Núms. 232-233 Julio-Diciembre 2010, 671-693
ISSN 2154-4794 (Electrónico) 
que se veía sujeta a directrices desde el mismo Ministerio del Interior -didactismo y prevención del crimen- o de las que luego serán más extensamente formuladas por Nogueras y Rodríguez Rivera. Estas pautas en las narrativas policiales que resumo a continuación revelan el carácter utópico restrictivo que la revolución quiso exigirle a su producción cultural: 1 . El delincuente siempre se enfrenta al estado revolucionario. 2. El investigador forma parte del cuerpo de policía que representa al pueblo. 3. La labor del investigador se apoya en las organizaciones populares de la revolución, especialmente los CDR. 5. La investigación y resolución del crimen no dependen de una individualidad sino que se debe a un colectivo perfectamente coordinado. 5. El género expone las causas sociológicas y psicológicas del crimen (153).

Es claro que estas pautas rechazaban cualquier aspecto del presente de la producción de los textos que disintiera del orden utópico revolucionario. Más aun, estos disensos eran incorporados tímidamente en los textos a manera de los actos delictivos a eliminar: robos, homosexualidad, intentos de fuga, promiscuidad, vagancia, ausentismo laboral, superchería, etc. Todos estos “delitos” conformaban el afuera de la revolución como residuos de un pasado capitalista (Jiménez 96). La presencia de éstos, sin embargo, aparece casi como una excepcionalidad histórica. Si Chandler y Hammet habían puesto al descubierto los lados oscuros de la sociedad en la que vivían, escritores como Guillermo Rodríguez Rivera, Ignacio Cárdenas Acuña, Daniel Chavarría y Nogueras presentaban una realidad en la que Estado y pueblo formaban una única entidad armoniosa que impedía la emergencia de personajes conflictivos. Para Benjamin “el contenido social originario de las historias detectivescas es la difuminación de las huellas de cada uno en la multitud de la gran ciudad” (“país” 16) pero, en una sociedad sin fisuras, de CDRs, en la que cualquier desviación es rápidamente identificada, aquella potencialidad de la multitud se pierde y en su lugar asistimos a una masa "vigilada” y "vigilante”. Con notables excepciones como las de El cuarto círculo y Con el rostro en la sombra, las consecuencias de la preponderancia de una dimensión futurista en la narrativa policial, produjo novelas con muy poca profundidad psicológica y en las que el excesivo control ideológico dejó poco espacio para el suspenso y el enigma. Amelia Simpson termina por concluir que la reapropiación del género con la eliminación de aquellos elementos propios de la ideología capitalista conllevaría al debilitamiento de la efectividad de la ficción detectivesca (100).

Sin embargo, es posible ver en el mundo retratado de estas narrativas, un acercamiento no tanto a las críticas novelas negras norteamericanas, sino a las novelas victorianas en su tono desproblematizado. De modo que, los textos cubanos resultaron irónicamente, más conservadores que su contramodelo estadounidense escarnecido en el discurso calibanesco. La paradójica similitud con las novelas victorianas expone un problema que va más allá de las deficiencias formales de una readaptación del género. Demuestra hasta qué punto las concepciones teleológicas de la revolución, al repetir

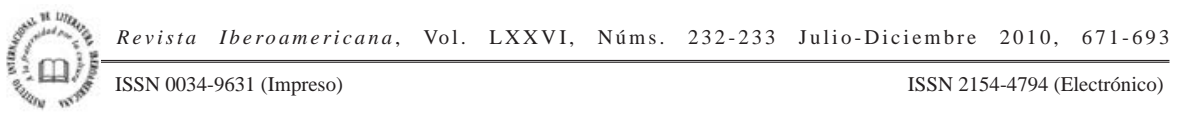


una lógica temporal progresiva, ahogaron una posible complejidad narrativa en aras de un programa futurista.

La PROMESA CALibánica en Y Si MUERo mañana de Luis Rogelio Nogueras

A partir de 1975 aparecerá otra variante del género con la aparición de las novelas de espionaje. Como la de detectives, este subgénero constituyó también una operación antropofágica. Esta vez el modelo devorado fueron las populares historias de autores como Ian Flemming. Ya Todorov habría mencionado la filiación de la novela de aventuras con la de espionaje, del mismo modo en que el thriller estaba vinculado a narrativas de viaje por su apelación a lo maravilloso y lo exótico (62). Todas estas narrativas expondrían universos ajenos, diferentes del propio. Si ya las novelas policiales anteriores resultaban maniqueas; el riesgo, como bien señalara Leonardo Padura, del puro partidismo y del "peligro de caer en el teque -el panfleto- [era] mucho mayor, ya que la esencia misma de la modalidad, en esta época, tiene que ver con el enfrentamiento entre dos sistemas sociopolíticos y económicos antagónicos" (“novela” 81). Esta puesta en escena de dos mundos antitéticos conllevó a que las representaciones desbordaran los límites de revolución/contrarrevolución interna para imaginar la dicotomía en términos de soberanía nacional.

La apropiación del género literario supuso repetir las polaridades morales propias de las narraciones “originales” británicas, pero invirtiendo las asignaciones valorativas para exaltar a la nación/revolución cubana. El mensaje se dirigía a un lector pasivo que debía asimilar las dicotomías morales de la solidaridad, el martirologio, el idealismo, el amor concretizados en el espía cubano, y, el individualismo, el materialismo, la tecnificación y la traición característicos de los agentes de la CIA y los cubanos exiliados en Estados Unidos. Estas novelas conservaron el carácter estático y dogmático que Simpson señala en las novelas de Fleming, dadas a presentar un mundo elemental sin distinciones críticas (121). Nogueras planteó las novelas de espionaje como batallas ideológicas "entre las fuerzas reaccionarias y el proletariado, entre el fascismo y el comunismo, entre el pasado y el futuro (énfasis mío, en Simpson 121). Más allá de las trasparentes distinciones de clase e ideológicas en las dicotomías de Nogueras, me interesa destacar la antinomia temporal como modo de aprehender a los Estados Unidos. El pasado no se limita a su sentido literal como referencia a los años de Batista superados por el comunismo, sino que también funciona para imaginar a los Estados Unidos como una alteridad en un momento temporal anterior, inextricablemente ligado a una anacrónica ingerencia colonialista.

En su libro Detective Ficition in Cuban Society and Culture, Stephen Wilkinson señala la necesidad de una cierta familiarización entre el lector y el mundo retratado en las novelas policiales (122). Acota que inclusive, en el género de ciencia ficción, los universos narrados apuntan siempre al futuro de la sociedad real en la que se vive

Revista Iberoamericana, Vol. LXXVI, Núms. 232-233 Julio-Diciembre 2010, 671-693
ISSN 2154-4794 (Electrónico) 
(122). Si esa dimensión presente es eliminada en las novelas de detective cubanas ante los imperativos de una utopía futurista, al desplazarse la narración a un territorio por fuera del espacio nacional, las novelas de espionaje permiten articular esa dimensión “real” situándola en el Imperio. A diferencia de la isla, el Estado y los individuos en los Estados Unidos no están amalgamados porque están históricamente “atrás” de la utopía. Sus fracturas son el terreno fértil para el delito y por qué no, para discretas complejidades psicológicas. De allí que, algunos hayan resaltado el atractivo de los personajes negativos de estas narraciones en contraste con sus contrapartes revolucionarias (Fernández Pequeño 214). De modo que si bien, la novela de espionaje entraña una limitación mayor en términos de la profundidad de sus personajes dado su expreso maniqueísmo ideológico, obtendría cierta licencia al permitirse imaginar aquello que es negado dentro de la isla.

Y si muero mañana de Nogueras (1978) constituye el mejor ejemplo de cómo el desplazamiento de la acción narrativa principal fuera de Cuba posibilita la hondura psicológica de los personajes. La novela narra los avatares del espía cubano Ricardo Villa Solana -de nombre encubierto Bruno- en Estados Unidos, en su misión por abortar una invasión armada en el puerto de Cienfuegos. Esta historia principal se ve entrecruzada por otras líneas temporales paralelas sobre la vida personal de Ricardo: sus inicios en la lucha contra Batista a los 17 años, su partida cinco años atrás a los Estados Unidos con una identidad secreta, sus inicios y ascenso en diversos grupos terroristas cubano-americanos de Miami y, el nudo dramático afectivo más importante, su historia de amor frustrado con Yolanda. La labor de Bruno es enviar regularmente mensajes a través de una vieja planta transmisora a sus compañeros en La Habana: el Capitán Riquenes y el teniente Rodolfo Sarduy. Estos mensajes informan sobre las actividades anticastristas en Miami.

El 17 de septiembre de 1968 se produce un ataque contra el poblado cubano de Boca de Pájaro y Bruno tiene la obligación de averiguar quiénes son sus autores. Si se trataba de la CIA o de alguna de las facciones anticastristas de manera independiente: la de José Torres, que concentraba el mayor poder al controlar todo el exilio de Miami, o de algunos de los líderes en Nueva York: Roberto San Gil o Mignolo Arteaga. Ricardo rápidamente descubre que el evento tan sólo forma parte de la operación "Estigma”, la cual culminaría con un ataque mayor al puerto de Cienfuegos cuatro días después. Su última misión antes de morir consiste en poner sobre aviso a través de la radio a Riquenes y a Sarduy.

La organización de Estigma había sido responsabilidad de Roberto San Gil de espaldas a la CIA y a las demás facciones. Todos los grupos cubanos en el exilio aparecen enfrentados entre sí, a manera de bandas mafiosas que rivalizan por el apoyo estadounidense y que no dudan en eliminarse unos a otros pragmáticamente. Personajes como Torres además, usufructúan los recursos que ingenuamente los exilados le entregan con la esperanza de derrocar a Fidel y regresar a la isla. Entre ellos no escasean personajes

Revista Iberoamericana, Vol. LXXVI, Núms. 232-233 Julio-Diciembre 2010, 671-693 ISSN 0034-9631 (Impreso)

ISSN 2154-4794 (Electrónico) 
de baja calaña como anexionistas, gente que cambia de nacionalidad desechando la cubana eintelectuales arielistas afrancesados vendidos al oro de Hollywood. La amenaza proveniente de todo este ámbito de corrupción moral sin embargo, es minimizada ante el verdadero poder de la CIA. Los jefes de la central norteamericana han dado la voz de alarma ante los sucesos de Boca de Pájaro. Molestos por el ataque inconsulto y ante la posibilidad de que alguna de las facciones del exilio se le haya ido de las manos, Kaplan ordena a Duke averiguar quiénes son los responsables de esa acción. Duke, a su vez, delega en su subordinado, Normand, esa tarea. El mundo de la CIA es el reverso especular de la inteligencia cubana. La cadena de mando Kaplan-Duke-Normand es una distorsión de la cadena Riquenes-Sarduy-Villa Solana. Mientras la relación entre los cubanos se levanta sobre el respeto, la solidaridad y el afecto, la de los estadounidenses se basa en la arrogancia, la competencia y la envidia. Los tres funcionarios cubanos como se ve, configuran el polo positivo de la narración. Su contrapartida está formada por dos grupos: los arieles que integran las diferentes facciones cubanas en Miami, Los Ángeles y Nueva York; y Próspero: los agentes de la CIA que habían entrenado, financiado y controlado con éxito a los exilados cubanos hasta el momento en que se produce el ataque a Boca de Pájaro.

El narrador muestra a la inteligencia norteamericana con todas las fisuras propias de una sociedad individualista. Estas grietas se configuran alrededor del quiebre generacional. El elemento temporal resulta clave para satanizar a los agentes de la CIA. Con muchos años en los servicios secretos, Duke pertenecía a un pasado desplazado por los nuevos tecnócratas de inteligencia:

Sí: la Agencia había cambiado y él, Duke, se estaba volviendo viejo y sentimental [...] pensó con tristeza que ya quedaban pocos testigos de la bella y bárbara época en que Dulles era el patrón de la CIA y Hoover el jerarca absoluto del Federal Bureau; entre esos pocos había un judío llamado Harry y un idiota de sesenta y cinco años llamado Stuart Duke, del que prescindirían tarde o temprano. Las nuevas generaciones que habían llegado con McCone (con su proliferación de cámaras video-cassetes) los estaban desplazando; los viejos zorros de Dulles y de Wild Donovan pasaban a retiro ante el empuje de los nuevos hippies del espionaje telefónico (21)

El personaje de Nomand por su parte, viene a configurar una suerte de "hombre nuevo" en negativo que desdeña el idealismo de las generaciones anteriores:

él, Mickey Normand, graduado en Harvard, de treinta y cinco años y buen aspecto, era el tipo de hombre que la CIA necesitaba. Los fósiles del dullismo habían quedado atrás. El mundo era otro y otras también las armas de la nueva inteligencia. La Infantería de Marina lo había endurecido, pero más aún lo había endurecido su trabajo en el centro secreto de pruebas de armas químicas, biológicas y sicológicas en Dugway, Utah. Allí, como adjunto de la CIA, había visto de frente el rostro de la guerra moderna, una guerra

Revista Iberoamericana, Vol. LXXVI, Núms. 232-233 Julio-Diciembre 2010, 671-693
ISSN 0034-9631 (Impreso) 
para la cual hombres como Duke [...] no estaban preparados: aerosoles capaces de producir alucinaciones y la muerte, ultrasonidos enloquecedores, microbios a los que una mutación genética convertía en asesinos. La guerra invisible, total. (31)

La tecnificación de los servicios de inteligencia -aquello que las novelas de espionaje británicas exhibían y celebraban espectacularmente-supone una señal visible de la decadencia de la sociedad norteamericana. Como José Enrique Rodó al referirse al utilitarismo anglosajón, Nogueras equipara la tecnificación a un pragmatismo falto de espiritualidad. Los "nuevos hippies" representados por personajes como Normand destacan tanto por su destreza técnica como por sus carencias morales. Ante esta nueva generación, los ancianos todavía conservan un matiz ético, aún si se trata de agentes de la CIA como Duke.

La ausencia de escrúpulos de Normand, quien provoca la muerte de Roberto San Gil, responsable de la operación Estigma y la del mismo protagonista Ricardo Villa, desentona con su contraparte cubana. La carencia de recursos tecnológicos cubanos es compensada por su superioridad moral. Este contraste dramatiza los términos de la confrontación política explícitos en la misma novela: "Un punto de tierra fértil en el mar Caribe, un pequeño país pobre, sólo podía vencer a costa de valor, astucia y fe: valor para saber morir de pie, sin una queja; astucia para luchar en condiciones tremendamente desventajosas, fe en Fidel, la Revolución, el provenir”(135). La parábola de David y Goliat se reformula en el simbolismo de Calibán. David logra vencer al gigante apropiándose de sus armas: la tecnología. La mayor metáfora de esta estrategia la constituye el radio-transmisor de Ricardo, gracias al cual evita el éxito de los ataques contrarrevolucionarios:

Ricardo no había tenido en los Estados Unidos otra cosa que una planta trasmisora RT48A, una planta transmisora fabricada por la Rank Corporation para la CIA, enviada a Cuba clandestinamente para uso de la contrarrevolución interna, capturada por el DSE cubano y devuelta en secreto a los Estados Unidos, para equiparar al "pianista” Bruno. Era una enorme y trágica paradoja para el gran país todopoderoso, y una victoria moral para el pequeño país. (135)

La victoria de Ricardo sobre Normand es moral. Contemporáneos ambos, el cubano y no Normand, configura ese futuro que Nogueras buscaba contraponer al pasado satanizado en sus dicotomías propuestas para la novela de espionaje. El ejecutor de la "guerra moderna" expresa más un joven "degenerado" asociado a un pasado a "superar” que uno viril y saludable. La hipócrita sumisión al jefe y sus impresionantes destrezas técnicas funcionan como encantadores artilugios que esconden una psicología decadente. Del mismo modo, las grandes ciudades norteamericanas hechizan con sus espejismos de modernidad en la novela. En una inversión de la mirada hegemónica

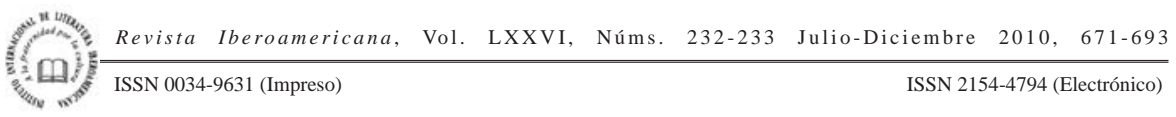


sobre la gran ciudad, Ricardo contempla Nueva York desde el Empire State, muy cerca de las construcciones del World Trade Center:

New Yok aparecía humana. El dolor, la lucha por la vida de aquel hormiguero que se movía incesantemente en las arterias de Manhattan, las abismales diferencias de clase y de razas, desaparecían desde aquella altura [...]

Pero Ricardo había visto -tocado-el magma vivo que palpitaba allá abajo; había estado entre aquellos hombres y mujeres. Había visto mucho. Había vivido. Había tomado el pulso de aquel país, enfermo de cólera, altivez y miedo” (énfasis mío 49-50)

La idea de una modernidad engañosa, patológica, es recurrente. En Miami, por ejemplo, la calle Flager alucina por los múltiples objetos de las tiendas: tocadiscos, grabadoras, aparatos de cocina, refrigeradores, armas de fuego, equipos deportivos, lavaplatos, cosméticos, alfombras, bicicletas, etc. con los que la diáspora cubana delira obsesivamente (71). Miami culmina siendo una "fusión de vanas esperanzas, malos sueños, desquites, componendas, estafas, manejaos turbios, fanfarronerías, mentiras, bravuras de café con leche, buenas tajadas, pésimos negocios y miedo” (75). Las atrayentes Sodomas del capitalismo parecen fatalmente enfermas, atomizadas por el racismo, clasismo, individualismo y el consumismo. Sus habitantes del exilio cubano dramatizan la "dolencia" de la dependencia cultural norteamericana denunciada por Fernández Retamar.

Contrariamente, La Habana es el espacio depositario de los "verdaderos" valores, como las metáforas del café en contraposición "del brebaje insípido" del paladar norteamericano (134) o del idioma español, "no el español en conserva que se maltrata en Miami [...] a medio camino entre el inglés y el caló de Pila y Colón” (35). Los episodios que tienen lugar en Cuba tienen una connotación idealista, generalmente están relacionados a la épica revolucionaria o a la memoria afectiva del personaje. Si Estados Unidos es el ámbito de Normand, calculador y frío, la memoria de Ricardo se retrotrae a la idílica playa en el que tuvo lugar su último encuentro amoroso con Yolanda.

Sin perder su dimensión idealizada, Ricardo sin embargo, se despega del acartonamiento habitual en este tipo de protagonistas. Separado de su verdadero amor por la lucha contra Batista, Ricardo se ve impelido a separarse nuevamente de Yolanda al abandonar Cuba e irse a Miami. Al no poder revelarle el verdadero motivo de su partida, ella -militante del PCC-, lo cree un traidor de la revolución y lo rechaza. La introducción del elemento sentimental permite un acercamiento con el lector al suponer un tipo de pedagogía que expone las tensiones sufridas por el cubano medio entre sus requerimientos individuales, afectivos y los imperativos de la revolución. El capitán Riquenes recuerda que Bruno: "había roto con sus compañeros, con su pasado para irse marginando de la revolución y finalmente marcharse hacia Miami a una misión larga y difícil” (44).

Revista Iberoamericana, Vol. LXXVI, Núms. 232-233 Julio-Diciembre 2010, 671-693
ISSN 2154-4794 (Electrónico) 
La paradoja de la novela es que la efectividad dramática del personaje revolucionario es posible debido al contexto capitalista en el que se mueve, que lo obliga a ocultar sus sentimientos aislándose de sus seres queridos. Ello posibilita un perfilamiento individual imposible en la isla en donde los personajes están refundidos con el Estado.

La soledad del personaje apunta a una concepción revolucionaria basada en el dolor y últimamente en la muerte. Lo que el capitán Riquelmes y Bruno tienen en común es "una misma fidelidad a la sangre derramada para que esa tierra sea alguna vez el lugar hermoso en el que correrán libres los hijos del comunismo" (62). Como lo exaltaba Portuondo, la sangre es el atributo moral de la superioridad literaria y últimamente, revolucionaria.

La novela abre y cierra con las imágenes de Ricardo mortalmente herido. Nogueras no economiza imágenes de violencia. Después de haber logrado escapar varias veces de los esbirros de Normand, el cubano muere en una lucha entre Karate y Kun Fu con un asesino chino contratado por la CIA. En la pelea final nuestro protagonista agonizante vence a su adversario y logra enviar el mensaje segundos antes de expirar. Su última lucha había sido sin artefactos, en un cuerpo a cuerpo, metaforizando la pureza ideológica del personaje frente a la artificiosidad negativa de los funcionarios de la CIA.

En su carta-testamento Ricardo declara las siguientes palabras que resumen la mística revolucionaria y que dan título a la novela: "Si muero mañana, será para que siga viva la esperanza de un hermoso porvenir" (169). Ricardo emula ejemplarmente el ejemplo de Martí, el Che y aquellos que al momento de la publicación de la novela se encontraban luchando en Angola. A aquellos que murieron lejos de la patria tras la consecución de sus ideales les dedica Nogueras la novela, con la promesa del "alba del día de la batalla final” (5). El reconocimiento glorioso, como el de la misma Yolanda al enterarse de la verdadera historia de su amado, se siembra sobre cadáveres desperdigados fuera de la patria.

La idea de un provenir utópico que exige el sacrificio de los cubanos se anuncia desde la dedicatoria y atraviesa toda la narración. Esta idea se propone como la antítesis de la sociedad norteamericana. El aspecto idealizador de la muerte coincide con la visión romántica de un conjunto de intelectuales alemanes como Werner Sombart, Oswald Spengler y Ernst Jünger de principios de siglo xx, para quienes "lo que realmente resulta despreciable es el acobardado hábito burgués de aferrarse a la vida, de no desear la muerte por altos ideales, de rehuir el conflicto violento, de negar el aspecto trágico de la vida” (Buruma y Margalit 62). La Cuba revolucionaria se legitima sobre una posteridad sembrada de cadáveres, convirtiendo literalmente la consigna "Patria o muerte" en su corolario Patria "y” muerte. El progreso socialista; progreso al fin y a la cabo, va sembrando sus propias ruinas. La superioridad moral en realidad, está planteada en el razonamiento teleológico denunciado por Benjamin en su conocido texto Sobre el concepto de la historia, en el que el presente desaparece, como desaparece el

Revista Iberoamericana, Vol. LXXVI, Núms. 232-233 Julio-Diciembre 2010, 671-693 ISSN 0034-9631 (Impreso) 
protagonista Ricardo aplastado por el futuro y distanciado por completo del pasado. El disciplinamiento de la ética revolucionaria, al posponer el paraíso en un futuro inalcanzable, repite el drama referido por Giorgio Agamben de estar sometido a un tiempo lineal y continuo (154). La felicidad, como reflexiona el mismo Ricardo, se vuelve un imposible, un valor burgués o contrarrevolucionario:

\begin{abstract}
Yolanda y yo hacíamos planes. ¿Quién no los hace cuando es joven? Queríamos casarnos, tener hijos, ser felices. Pero ¿quién no piensa en casarse, tener hijos, ser feliz? Después sabríamos que la felicidad es sólo uno de los rostros de la vida, como el sufrimiento o el cumplimiento del deber. La felicidad, como entonces la imaginábamos, no existía (énfasis mío 87)
\end{abstract}

Desterrar la imaginación como lugar de la experiencia, ¿̇no es sino reafirmar aquello que se critica: el monopolio del cientificismo y de la hiperbolizada tecnología como instrumentos de conocimiento/poder? ¿No es sino ratificar aquello que Benjamin entendía como la discrepancia entre los tremendos medios de producción y su inadecuada utilización del proceso de producción? (“work” 15). Desdeñar la idea de felicidad ¿no entraña la repetición denunciada por Agamben del sometimiento a la tiránica mensurabilidad del cristianismo y del capitalismo, en el que el placer se vuelve una postergación infinita? (153)

La extensa producción de novelas detectivescas y de espionaje cubanas dramatizó la contradictoria rebeldía de Calibán en donde la apropiación corrió el riesgo de perpetuar lo reciclado. En este caso, el intento estribó en una autolegitimación a partir de la misma concepción historicista hegemónica. No es de extrañar que el revitalizamiento cubano del género en los años noventa se propusiera distanciarse de las novelas de este período.

CALIBÁN FRENTE AL ESPEJO

Con su primera novela en 1990 de la tetralogía Pasado Perfecto, Leonardo Padura buscó interpelar las narrativas heroicas detectivescas de las décadas anteriores. Al hacerlo desde un presente ficcionalizado por aquéllas, tuvo un efecto demoledor sobre la anterior visión triunfalista. Con el personaje del policía Mario Conde parecían quedar sepultados aquellos calibanes beligerantes de las novelas aupadas por el MININT. Padura sin embargo, no renuncia a cierta lógica antropofágica al retomar el género para dotarlo de una especificidad cubana. Lo hace no obstante, sobre las ruinas no ya de aquel universo capitalista en decadencia denunciado por Portuondo años atrás (78), sino sobre las ruinas del propio estado socialista: "mi propósito claro fue hacer novelas policiales muy cubanas pero que no se pareciera en nada a las anteriores novelas policiales cubanas” (en López 166).

\begin{tabular}{l} 
Revista Iberoamericana, Vol. LXXVI, Núms. 232-233 Julio-Diciembre 2010, 671-693 \\
\hline ISSN 0034-9631 (Impreso)
\end{tabular} 
Esta diferenciación forma parte de lo que Padura denomina el neopoliciaco latinoamericano, un subgénero mucho más cercano al hardboiled norteamericano y que estaría representado por autores como Rubem Fonseca o Paco Ignacio Taibo II. En Cuba, la necesidad de distanciarse de las pautas oficiales establecidas años atrás tiene su origen en el quiebre histórico del año 89. Perteneciente Padura a la primera generación cubana nacida y/o criada bajo la revolución, aquella fecha acabó dramáticamente con el mundo utópico que describían las novelas policiales de los años setenta y ochenta:

El futuro pertenecía por completo a ese ideal [del socialismo]. Se trataba de una marcha ascendente hacia metas históricas indetenibles. Cuando esta generación llega a los treinta años, se produjo la caída del muro de Berlín y la desaparición de la Unión Soviética. Comenzó entonces en Cuba una crisis económica e ideológica muy violenta. (en López 163)

El fin de la guerra fría supuso para la generación de Padura la irrupción definitiva de una catástrofe. No es casual que su tetralogía policial esté ambientada en el año 89 y que culmine con la llegada de un huracán devastador sobre La Habana. Este huracán pone fin a la excepcionalidad cubana -ese "mundo perfecto" parafraseando la primera novela de la tetralogía de Padura- e inscribe la territorialidad de la isla en un espacio similar al de sus pares latinoamericanos. En su artículo "Ficciones cubanas de los últimos años”, Josefina Ludmer plantea que el fin de la guerra fría abrió dos procesos que resultaron en cierta forma equivalentes: "la implantación del régimen especial en Cuba, y el triunfo de la globalización neoliberal en el resto de Latinoamérica” (357). Los efectos de ambos procesos producirían consecuencias similares: "Cuba, con la caída de la Unión Soviética, comienza a depender tanto de los extranjeros, de los dólares y de la industria del libro español como el resto de Latinoamérica” (357). ${ }^{2}$

El posicionamiento de una generación única que sufrió este cambio ha dado lugar en Cuba a su común denominación como generación del desencanto3: "todo desencanto presupone tanto la creencia como la extinción de la fe en una utopía. Los escritores de la generación siguiente [...] no arrastran consigo el encantamiento que marcó la vida de sus predecesores” (Fornet, "narrativa” 45). Ello no implicó necesariamente un rechazo a los ideales revolucionarios, sino "una frustración más que un trastorno ideológico" (Fornet, Nuevos 56). Así lo testifica el mismo escritor: "Redescubrimos la historia y nuestra percepción cambió. Comenzamos a sentir que nos habían engañado. Junto con

2 La entrada en una (pos)modernidad capitalista, va a hermanar ciertas narrativas cubanas de los escritores más jóvenes -los llamados novísimos- con otras de América Latina que ya estaban teniendo lugar a partir de ciertos temas del posboom.

3 O "generación escondida” según uno de los personajes de Padura.

Revista Iberoamericana, Vol. LXXVI, Núms. 232-233 Julio-Diciembre 2010, 671-693 
ese engaño y con la crisis económica, mi generación experimentó un gran sentimiento de frustración” (en López 164).

El "engaño" es terreno fértil para las narrativas policiales. La frustración, por su parte, deriva en el escepticismo del detective propio de personajes como Sam Spade y Philip Marlowe. La complejidad social, perdida en las novelas anteriores, emerge en las de Padura a manera de simulaciones, mentiras, máscaras, apariencias que el Conde va revelando en sus investigaciones. La policial "Es una novela que enseguida te conecta con lo peor de la sociedad. Te coloca inmediatamente en su lado oscuro" (en López 166). Este lado oscuro señala inevitablemente a la misma revolución, a aquello que ésta ocultaba bajo la máscara de la utopía. El íntegro espía Ricardo Solanas, asesinado heroicamente lejos de su tierra en $Y$ si muero, es sobrepasado por la realidad. En 1989, el general Arnaldo Ochoa, héroe de Angola, protagoniza uno de los escándalos más demoledores de la mística revolucionaria. Termina siendo fusilado por su participación en el tráfico de drogas, escándalo que salpicó a otras altas figuras del Estado. Como el mismo Ochoa, los criminales literarios de Padura suelen ser altos personeros del gobierno, gente de apariencia respetable. La corrupción de estos personajes contrasta con cierta inquebrantabilidad ética del Conde y sus amigos de juventud. Testigos y víctimas de la frustración de la teleología socialista, los códigos éticos adquiridos en ese mismo pasado que ahora se derrumba ante sus ojos, se flexibilizan ante los imperativos individualistas de supervivencia, pero no se desechan. El viejo aliento de una sociedad pensada en colectivo hace de estos personajes seres incapaces de anclarse en una sola territorialidad. Como policía, el Conde permanece dentro los límites del estado; como individuo desencantado se coloca fuera de él. En ocasiones, ciertamente, el protagonista actúa por fuera de la ley cuando lo considera justo, aunque su función sea precisamente la de hacerla cumplir. De allí la paradoja señalada por Wilkinson; el desencanto se delata en su alienación de la sociedad cubana actual; al mismo tiempo, sus ética -asumida desde el pasado-, lo empuja a involucrarse en esa misma sociedad (179). Ludmer menciona la particular subjetividad de las "escrituras del presente" devenidas tras la caída del bloque soviético:

Los personajes de las ficciones (o los que la narración multiplica, fractura, vacía) se definen por su condición diaspórica: por su posición exterior-interior de la ciudad, la nación, el trabajo, la ley o la razón. Están fuera y adentro al mismo tiempo: afuera y atrapados simbólicamente en esas esferas. Y superponen lo privado y lo público en oscilación donde instalan afectos y pasiones (énfasis mío, 359)

Esta movilidad de la condición diaspórica entre un ayer y hoy, entre legalidad y justicia, entre comunidad e individuo, entre los afectos y el pragmatismo deriva en una condición de desengaño permanente que distancia a los personajes de la "volcánica

Revista Iberoamericana, Vol. LXXVI, Núms. 232-233 Julio-Diciembre 2010, 671-693
ISSN 2154-4794 (Electrónico) 
violencia” heroica del Calibán imaginado por Fernández Retamar. ${ }^{4}$ Las posteriores narraciones a la tetralogía de Padura indicarán un movimiento articulado por la memoria hacia la nostalgia y "la necesidad de creer en algo” (Uxo 30). En particular, esta apertura de la memoria permitirá en Adiós Hemingway (2000) reformular las estrechas antinomias de Calibán al revisar los imaginarios literarios de la Guerra Fría y la figura del escritor norteamericano.

\section{Reformulando los imaginarios de la Guerra Fría en Adiós Hemingway}

El 15 de mayo de 1960, el fotógrafo cubano Osvaldo Salas legó a la posteridad una famosa imagen de Fidel y Hemingway juntos. El encuentro entre las dos grandes figuras no sólo era el testimonio de la fortaleza de una revolución que apenas comenzaba, sino la manera en que ésta era capaz de apropiarse de uno de los grandes mitos literarios del siglo xx. La figura del revolucionario cubano parecía crecer en su proximidad con el premio Nobel para demostrar así, que era posible afirmar la propia legitimidad sobre el prestigio metropolitano. Sin embargo, lo que en el retrato parecía asegurar la utopía que se avecinaba, se trocó con el tiempo en la expresión de su fracaso. El imaginario hemingwayano fascina hoy a los centenares de turistas que acuden a monumentos y locales de acceso prohibitivos para el cubano medio. ¿Cómo conciliar la "glamourosa Marina Hemingway para que los ricos y hermosos burgueses del mundo y ningún zarrapastroso cubano de la isla [...] disfrutara de yates, playas, bebidas, comidas, putas complacientes y mucho sol” (Adiós 28); con la imagen del Hemingway solidario con una revolución que prometía acabar con las desigualdades y el racismo de la isla? La novela de Padura Adiós Hemingway propone una exploración de esta ambivalencia como una manera de reflexionar sobre la propia revolución. Al hacerlo, las dicotomías planteadas por Fernández Retamar se difuminan y la realidad -como la de la fotografía- empieza a adquirir varias dimensiones.

Ocho años después de su retiro de la policía, Mario Conde visita el museo de Finca Vigía. Una tormenta había descubierto un cadáver en la antigua casa de Hemingway. El hecho parecía ser la punta del iceberg de una vieja historia no resuelta. El teniente Manuel Palacios conmina a su antiguo colega a hacerse cargo del caso de manera extraoficial.

4 El mejor amigo del Conde, el flaco Carlos por ejemplo, resulta la contracara del teniente Solanas, no sólo no muere heroicamente en Angola, sino que regresa paralítico para permanecer postrado en una silla de ruedas bajo el cuidado de su madre. El Conde por su parte, es una versión paródica de aquel hombre nuevo imaginado por el Che: "Eres la elegancia misma, mira esa estampa, Mario Conde [...] un apetecible soltero de treinta y seis años, expolicía, prealcohólico, pseudoescritor, cuasiesquelético y posromántico, con principios de calvicie, úlcera y depresión y finales de melancolía crónica, insomnio y existencias de café” (Paisaje 237).

Revista Iberoamericana, Vol. LXXVI, Núms. 232-233 Julio-Diciembre 2010, 671-693
ISSN 2154-4794 (Electrónico) 
En realidad, la investigación compete más a la memoria que a la resolución del enigma. Develar al autor del crimen implica una disputa simbólica entre la marginación o la recuperación de una figura literaria cuya ambigüedad sugiere también la naturaleza de la revolución.

Hemingway había sido un personaje idolatrado durante la juventud del Conde cuando éste iniciaba sus primeros escarceos literarios. Era "el modelo ideal de lo que podía ser la literatura y de lo que debía ser un hombre con una vida hecha por y para esa literatura” (42). La precisión de sus narraciones, su engañosa transparencia lo fascinaban tanto como la vida desenfrenada, riesgosa y apasionada del escritor. Sin embargo, a medida que transcurrió el tiempo esa percepción fue cambiando:

La distancia se había ido forjando mientras el romanticismo dejaba espacios al escepticismo y el entonces ídolo literario se le fue convirtiendo en un ser prepotente, violento e incapaz de dar amor a quienes lo amaban; cuando entendió que más de veinte años conviviendo con los cubanos no bastaron para que el artista comprendiera un carajo de la isla; cuando asimiló la dolorosa verdad de que aquel escritor genial era también un hombre despreciable, capaz de traicionar a cada uno de los que lo ayudaron. (50-51)

El Hemingway corresponsal de guerra, republicano de la guerra civil española, perseguidor de submarinos nazis en el Caribe, aficionado al boxeo, cazador implacable, seductor de las más bellas mujeres del star system hollywoodiense; en fin, la definición hecha persona y literatura de "la hombría y el coraje” (68) se le había revelado al Conde como un tipo egocéntrico, sádico, fácilmente manipulable y traidor de sus amigos. Los lamentables episodios biográficos con amigos como Sherwood Anderson, John Dos Passos, Scott Fitzgerald y José Robles eran hechos que le pesaban al Conde enormemente, habida cuenta de la inquebrantabilidad de la amistad para él.

Establecer la culpabilidad o la inocencia de Hemingway en el crimen de Finca Vigía implicaba una elección entre ambas visiones sobre el escritor. La primera entraña el rescate de una memoria de la inocencia, la segunda la permanencia del sinsentido. Esta era la disyuntiva para el ex-policía:

En Conde sentía una extraña intranquilidad. Todos su prejuicios y deseos de descubrir la culpabilidad de Hemingway habían caído en el pantano de su memoria y ahora los veía hundirse dramáticamente, ante la certeza de que sus odios no podían ser más fuertes que su arcaico sentido de la justicia y la comprobación de que los libros y la figura de Hemingway, a pesar de todo, seguían siendo importantes para otras personas. (75)

La memoria aparece como un poderosísimo contrapeso de los odios y prejuicios. Ésta fluye en abundancia convirtiéndose en un posible recurso contra la atmósfera de desesperanza. Aunque al visitar Finca Vigía, el Conde reconoce el carácter sepulcral del lugar, los objetos petrificados en la vieja casona -libros, armas, animales disecados,

Revista Iberoamericana, Vol. LXXVI, Núms. 232-233 Julio-Diciembre 2010, 671-693
ISSN 2154-4794 (Electrónico) 
entre otros-, cobran vida en Adiós porque activan una memoria afectiva. Al acudir a la antigua casa de Hemingway, el detective rememora una excursión con sus amigos del preuniversitario; una mañana sabatina plena de camaradería y juventud en la que el Conde había leído frente a sus amigos, su cuento favorito del escritor norteamericano. Este episodio presenta un pasado en el que la admiración por el escritor tiene su paralelo en una inocencia revolucionaria. En el personaje Mario Conde la nostalgia adquiere un sentido positivo y doloroso en la medida en que recupera un universo revolucionario en el sinsentido del derrumbe socialista. El asunto en Adiós sin embargo, es si esta nostalgia es capaz de resignificarse en el presente.

El cadáver resurgido del pantano más que revelar la corrupción y decadencia de la sociedad actual -tal como sucede en la tetralogía anterior de Padura-, sugiere la existencia de una realidad subyacente diferente, productiva. Esta otra realidad queda sugerida en el juego intertextual con el relato de Hemingway “El gran río de los dos corazones” que el Conde lee a sus amigos en la excursión al Museo. La novela de Padura se estructura en dos planos temporales, las dos historias que Todorov señala en este género narrativo: la del crimen y la de la investigación (159). El uno se refiere a los avances del Conde en el caso, el otro a la noche del crimen en la Finca. Al igual que en el famoso cuento, un relato subyace bajo la cristalina superficie del otro. La investigación encubre la verdadera historia, esto es, la de los últimos años de Hemingway en La Habana.

Pero, ¿cómo penetrar la opacidad de aquel escritor? ¿Quién era realmente? Revisitar a Hemingway implica sumergirse en las profundidades de un imaginario alejado de toda premisa. Si el detective ha ganado complejidad en estas narraciones neopoliciales, sus contrafiguras también: los sospechosos y/o los criminales. Hemigway, como el cadáver resurgido del pantano, actúa como un significante abierto a múltiples significados.

Al tratar de reconstruir los eventos que rodearon el crimen, el Conde logra establecer vagamente la identidad de la víctima gracias al hallazgo de una placa del FBI enterrada junto al cadáver. La muerte había tenido lugar una noche de 1958 en la que las personas que acompañaban al escritor eran Calixto, el custodio del Finca; Raúl, su criado personal; Toribio, su gallero y Ruperto, pescador, capitán de su barco. El Conde se dispone a interrogar a Ruperto y Toribio, los únicos sobrevivientes. Sin embargo, la dimensión subjetiva de los recuerdos de ambos ancianos deriva en dos versiones muy diferentes de su jefe. Para Toribio de -102 años-, el "Papa" era un "tremendo hijo de puta” (79) que "tenía el demonio dentro" (81). Según el gallero, el escritor era un tipo de puras apariencias: "lo suyo era mucha gritería, mucha guapería con los animales, y mucha pantalla para que la gente se creyera que él era un timbalú” (88). Para Ruperto -de 89 años- por el contrario, Papa "fue como Dios” (125): "Papa fue para mí lo más grande del mundo [...]. Desde que lo conocí, hasta hoy, me ha dado de comer, y eso se agradece" (163).

A la novela no se le escapa la subordinación que estos hombres mantenían con un hombre que "exigía que le dijeran Papa”, que “decía que él era el papá de todo el mundo”

Revista Iberoamericana, Vol. LXXVI, Núms. 232-233 Julio-Diciembre 2010, 671-693 
(85). La visión de ambos ancianos conjuga la dinámica de amor/odio, de agradecimiento o de recelo, típico de las jerarquizadas relaciones paternalistas. El narrador está consciente de la tensión de este tipo de relación entre el patrón y sus sirvientes. El tema del nativo sumiso, del Ariel tan despreciado por Fernández Retamar, reaparece nuevamente en la figura del criado mulato. Tenorio, el actual guía de Finca Vigía le comenta al detective sobre el mayordomo Raúl: “Cuando Hemingway llegó a la Vigía, Raúl era un huérfano mataperros que se estaba muriendo de hambre. Hemingway casi lo adoptó, le cambió la vida, lo hizo persona, lo ayudó a construir su casa, fue el padrino de su hija [...], y claro que Raúl veía por los ojos del patrón” (56, énfasis mío). La subordinación de Raúl contrasta con la actitud del gallero, quien se había ido a las manos con su jefe cuando éste descubrió que le robaba sus huevos. La tensión entre sumisión y rebeldía es constante en la relación que se establece con Hemingway. La novela sugiere la imagen de un grupo "de tigres adiestrados, pero tigres al fin y al cabo" (126). Ni la novela, ni el detective idealizan esta relación de patronazgo. En la historia paralela que nos relata la noche del homicidio, acudimos a varios diálogos entre Hemingway y sus empleados, muy breves por demás. Ellos se caracterizan por una parca cordialidad que delata la inteligibilidad entre unos y el otro. Sus empleados son ajenos a las tribulaciones del atormentado escritor. Por su parte, éste permanece también ajeno al universo de aquéllos. $\mathrm{Al}$ acercarse Hemingway al lugar donde Calixto vigila la Finca mientras escucha la radio, se nos dice: "No entendía aquella capacidad de los cubanos de pasarse horas y horas escuchando música, en especial aquellos boleros lacrimógenos y las rancheras mexicanas que tanto le gustaban a Calixto. En realidad eran muchas las cosas que no entendía de los cubanos” (98). La novela entonces, remarca la impenetrabilidad de dos mundos muy diferentes para, sobre esa opacidad mutua, levantar las semillas del enigma. La supuesta sumisión de Raúl le hace sospechar al Conde: "aquella relación de dependencia podía ser inicio de una trama peligrosa” (57). Como la imagen de los tigres amaestrados, Padura retoma las problemáticas del amo y del esclavo, de la relación centro-periferia. El mismo Conde había emulado ciegamente al ídolo literario en sus primeros años. La jerarquía entre el escritor estadounidense y sus pares cubanos se enfatiza en las temporadas en que aquél vivía en la isla. En todos esos años, Hemingway expresó un marcado desdén por los escritores y artistas cubanos, con los que nunca quiso involucrarse, según nos cuenta la novela.

No obstante, Padura está interesado en huir de las cómodas dicotomías políticas del imaginario calibánico de los años setenta. Hemingway es un personaje difícil de encasillar en relación a su propio país de origen. Dramatizaba simultáneamente el mito americano y su revés. Era el frívolo escritor codeado con las luminarias de Hollywood y al mismo tiempo el tosco borracho que departía con los pescadores de Cojímar. Era el gunman salido del midwest y el cosmopolita fascinado por las corridas de toros españolas. Era el popular escritor perseguido por los periodistas, pero también por los servicios de inteligencia americana. Era el gran patriota que combatió al nazismo o el gran traidor

Revista Iberoamericana, Vol. LXXVI, Núms. 232-233 Julio-Diciembre 2010, 671-693
ISSN 2154-4794 (Electrónico) 
comunista. Era tremendamente norteamericano y tremendamente antinorteamericano. Era, como la metáfora del iceberg que él propuso para sus narraciones, un hombre visible e invisible al mismo tiempo. Hemingway comparte con el Conde su condición de haberse colocado dentro y fuera del sistema, habría también en él cierta “condición diaspórica”. Dado que todo acto criminal implica una trasgresión, la novela está mucho más interesada en esas zonas oscuras del personaje que pudiesen vincularlo al homicidio.

Padura escoge un momento vital del escritor que se asemeja a la situación existencial de la generación del Conde. De allí cierta familiaridad a pesar de la impenetrabilidad con el personaje. El lector asiste al Hemingway envejecido de los últimos años con dificultad para escribir, psicológicamente deprimido y físicamente deteriorado. Un Hemingway que debe resignarse a una vida llena de privaciones totalmente diferente a sus experiencias en el pasado:

empieza a vivir prohibiciones: no puede comer, no puede tomar, no puede viajar [...] Empieza a deteriorarse físicamente y ese deterioro tiene una repercusión psicológica que le impide hacer el tipo de vida que hacía antes. Al perder su vida habitual, se encuentra con que el tiempo le cobra otra dimensión y empieza a tener más dificultades para escribir. Éste es un Hemingway envejecido que ha pasado por un tratamiento de electroshock demoledor para una persona que trabaja con su mente, con las palabras. De allí en adelante comienza una decadencia que finalmente lo lleva al suicidio. (en López 65)

La decadencia del escritor está fuertemente asociada a la pérdida de su memoria. Para el Conde, la impotencia creativa de Hemingway se debe mayormente a los electroshocks a los que fue sometido por sus supuestos delirios persecutorios (161), un tratamiento que, sospechosamente, terminó por castrarlo.

La desesperanza del Hemingway de los últimos años es análoga a la de una generación para la cual no parece haber futuro. Se trata de una percepción compartida por narrativas cubanas recientes: "las historias nacionales características de los clásicos se borran para dar paso a una suerte de crónica de un presente puro [...] sin futuro, que envuelve al pasado en forma de memoria y duelo" (Ludmer 360). Sin embargo, la frustración de personajes como el Conde, su falta de futuridad, adquiere una connotación positiva en tanto suscita una memoria productiva. El duelo permite entonces la apropiación de una realidad ya perdida que en esta novela se transforma por obra y gracia de la memoria en el "lado real” del escritor norteamericano (en López 165). Se trataría de rescatar un Hemingway que "se parece mucho más a la persona que realmente debió haber sido porque tiene que apartarse de los grandes escenarios que él mismo había propiciado para su biografia” (en López 165).

Este Hemingway "verdadero" es el personaje que se nos muestra la noche del homicidio. Uno que, a pesar de las prohibiciones médicas, divagaba aquella noche sobre su pasado mientras bebía con más generosidad de la debida, acompañado de su

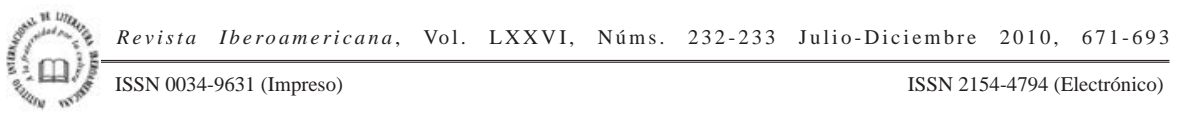


fiel Black Dog. Antes de acostarse había decidido dar unas vueltas por la Finca para asegurarse que todo estaba en orden. Uno de sus empleados le había avisado sobre el hallazgo de la placa de un agente del FBI en las inmediaciones de la casa. Hemingway veía así confirmadas sus supuestas paranoias. Tras breves diálogos con Calixto y René, Hemingway se retira a su casa amparado por su Thompson. Ya en su habitación el escritor se asegura de guardar su revólver 22 envuelto en el blúmer de Ava Garder -recuerdo de mejores tiempos-, en una mesa de noche antes de quedarse dormido. Al abrir nuevamente los ojos, se encuentra frente al agente John Kirk, quien lo amenaza con su 22. Si los antagonistas estadounidenses se caracterizaban por el mismo tono grandilocuente de los héroes cubanos en las novelas de espionaje donde eran mostrados como malvados, peligrosos, poderosos, fríos y calculadores, aquí el agente del FBI asemeja la imagen del otro lado del espejo del mismo Hemingway: un hombre de edad avanzada, alcoholizado, cojo, con una gran barriga y dientes deteriorados por el tabaco:

este agente del FBI que yo coloco en la novela, es un hombre que ya está prácticamente a punto de jubilarse, un alcohólico. Con ello traté de buscar una anti-imagen del Agente del FBI, una imagen anti-heroica en todos los sentidos. Sin nada de fortaleza, de agilidad de tecnología, de inteligencia. Se trataba simplemente de un burócrata de la investigación. (en López 165)

Kirk es la antítesis del Stuart Duke de Nogueras. Una sátira lastimosa dirigida contra los imaginarios de la guerra fría. Kirk supone la disolución de los grandes mitos sobre el enemigo. Con sesenta años, artrosis, una rótula mal soldada, y abandonado a su suerte en una isla tropical agobiante, el agente para colmo ha perdido su arma y su insignia. Su confrontación con Hemingway por el reclamo de éstas, muestra el fin del reinado de los prósperos y los calibanes. Para el mismo Hemigway, la muerte "se había convertido [...]) en una de sus obsesiones, sobre todo porque ya había pasado el tiempo de morir joven y también de hacerlo heroicamente” (92). Así, sin nada de heroísmo muere Kirk, abaleado por la espalda a manos de Calixto y Raúl en un intento por defender a su patrón del visiblemente nervioso y agresivo agente del FBI.

En el impasse entre Hemingway y su agresor, el primero insiste en saber cuál es la información sobre su vida recopilada en los archivos de Hoover. Las supuestas simpatías comunistas y la posibilidad de que hubiese donado dinero a los revolucionarios confirman lo que el escritor sospechaba pero que nadie nunca creyó: que lo estuvieron vigilando por años. Sin embargo, ni Hemingway, ni el Conde llegan a descubrir lo que subyace exactamente en aquellos archivos. Esa otra historia plasmada en los records permanece inaccesible. Kirk muere para ser enterrado anónimamente en Finca Vigía con la ayuda adicional de Toribio y Ruperto. La narración de la historia del crimen nos hace saber que Hemingway tomó la importante decisión de proteger a sus empleados a costa de no poder demostrar aquello que denunció durante toda su vida y que le valió destructivos

Revista Iberoamericana, Vol. LXXVI, Núms. 232-233 Julio-Diciembre 2010, 671-693
ISSN 2154-4794 (Electrónico) 
tratamientos psiquiátricos: estar vigilado constantemente por el gobierno estadounidense ${ }^{5}$. A Calixto lo envió a su soñada Veracruz con una buena cantidad de dinero. El resto, fue el profundo silencio sobre lo ocurrido que mantuvo hasta el final de sus días. El crimen sella un pacto secreto entre todos estos hombres y salva la imagen de Hemingway para el Conde, quien aunque nunca sabrá con certeza quién fue el homicida, ni el por qué había una gente del FBI en la Finca, logra recuperar al ídolo de su juventud por ese gesto de lealtad con sus amigos, sus empleados. El expolicía termina por preferir entonces otra imagen del escritor en la que sí “recibía una inquietante sensación de veracidad”. Se trataba de una de las últimas fotos de un Hemingway disminuido, envejecido que "miraba en pensativo silencio algo que no se podía apreciar en la fotografía” (181). Es en la opacidad de los personajes -que señala también los lados ocultos de la historia para el Conde: el verdadero criminal, las páginas del dossier del FBI, los motivos de la presencia de Kirk en el lugar- que emerge una ética liberadora. El cadáver en Finca Vigía termina por develar/encubrir una memoria positiva: la valoración de la amistad.

La recuperación de esta memoria por la vía de la reafirmación de códigos éticos adquiridos durante la revolución supone una alternativa frente al desencanto de la generación del Conde. Se trata sin embargo, no de recobrar al Hemingway rutilante, creado por sí mismo y recreado por los imaginarios oficiales de la revolución, sino de aquel que desde sus propias miserias fue capaz de comportarse dignamente. No es su mito lo que interesa, sino la memoria de un Hemigway sencillo y oculto que alguna vez se sentó humildemente a beber con los pescadores de Cojímar para escuchar sus historias. Ese Hemingway salvado por y para la memoria supone una relación distinta con esos "otros" que hasta ayer permanecían confinados a dinámicas binarias.

$\mathrm{Al}$ principio de la narración el guía de Finca Vigía, Tenorio -quien resultara ser el nieto del criado Raúl- le comenta al Conde sobre los "hemingwayanos cubanos". Cuando el detective, intrigado, le pregunta de qué se trata, éste le responde que ni de una logia ni de un partido

somos gente a la que nos gusta Hemingway. Y hay de todo: escritores, periodistas, maestros, y amas de casa y jubilados.

-¿Y qué hacen los hemingwayanos cubanos?

-Pues nada, leer a Hemingway, estudiarlo, hacer coloquios sobre su vida.

-¿Y quién dirige eso?

-Nadie..., bueno, yo un poco organizo a la gente, pero no los dirige nadie.

-Es la fe por la fe, pero sin curas ni secretarios generales. No está mal eso -admitió el Conde, admirado por la existencia de aquella cofradía de crédulos independientes en un tiempo de incrédulos sindicalizados (54)

5 Una lectura posible sobre los archivos secretos por los que reclama Hemingway apuntaría a las prácticas de vigilancia permanente de la revolución cubana. Sobre la relación entre vigilancia, tortura y ruinas reflexiona Antonio José Ponte en su libro La fiesta vigilada.

Revista Iberoamericana, Vol. LXXVI, Núms. 232-233 Julio-Diciembre 2010, 671-693 
Cuando Tenorio le pregunta al Conde si él también es hemingwayano, el ex-policía le responde que había devuelto el carnet. La decepción inicial del detective en las primeras páginas de la novela -su falta de fe en el escritor norteamericano-, cambia con su decisión posterior de pedir su entrada en los hemingwayanos cubanos al finalizar el relato. Lo que se recupera es una fe ahora liberada de imposiciones, de constreñimientos, de reglamentaciones. El Hemingway de Tenorio ya no es el de su abuelo, de la misma manera que el del Conde tampoco es el del héroe admirado ciegamente en su juventud. El escritor norteamericano se ha transfigurado en un imaginario democratizador que permite la supervivencia de la fe.

En la última escena de la novela, el Conde, junto con sus amigos el Conejo y el flaco Carlos -reconvertidos todos a hemingwayanos cubanos- beben frente al mar en el pueblo de Cojímar. El Conde les revela una última sorpresa sobre el caso: se ha robado el famoso blúmer de Ava Gardner de Finca Vigía. Objeto de deseo a lo largo de toda la narración, el fetiche recupera el carácter aurático de un pasado que parecía tan perfecto como la mujer que llevaba aquella prenda interior. Reconquistar ese espacio de la fe como una presencia que delata la ausencia de lo ya ido, es el obsequio que los tres amigos hemingwayanos hacen a Andrés, otro compañero del grupo que se ha marchado a los Estados Unidos hace 7 años. Los tres amigos hemingwayanos arrojan al mar una botella mensajera con el blúmer de la Gardner junto con otros pequeños escritos de amistad y de nostalgia para que llegue hasta Andrés en el exilio. En ella reafirman sus lazos afectivos por encima de territorialidades escindidas e ideologías separadoras. La botella, como la novela misma, porta el fin de los maniqueísmos de los imaginarios de la guerra fría, relativiza el espacio de los unos y de los otros. Si Hemingway se cierne como posible alegoría cultural de Estados Unidos, es claro que ha habido una transformación en la imagen de ese país. Como la metáfora del mar en el que se va alejando la botella, la revolución parece ser, así como el mismo Hemingway, "esa zona oscura donde sólo es posible ver algo con los ojos de la memoria y el deseo” (190).

\section{BiBLIOGRAFÍA}

Agamben, Giorgio. Infancia e historia. Buenos Aires: Adriana Hidalgo Editora, 2007. Benjamin, Walter. “El país del segundo imperio en Baudelaire”. Iluminaciones II. Poesía y capitalismo. Jesús Aguirre, trad. Madrid: Taurus Humanidades, 1991. 21-120.

"The Work of Art in the Age of Mechanical Reproduction". <http://design. wishiewashie.com/HT5/WalterBenjaminTheWorkofArt.pdf>

Fernández Pequeño, José M. "La novela policial cubana ante sí misma (1979-1986)”. La palabra y el hombre: Revista de la Universidad Veracruzana 70 (1989): 205-16. Fornet, Jorge. Los nuevos paradigmas. Prólogo narrativo al siglo XXI. La Habana: Letras Cubanas, 2006.

\begin{tabular}{l} 
Revista Iberoamericana, Vol. LXXVI, Núms. 232-233 Julio-Diciembre 2010, 671-693 \\
\hline ISSN 0034-9631 (Impreso)
\end{tabular} 
“La narrativa cubana entre la utopía y el desencanto”. La Gaceta de Cuba 5 sept.-oct. (2001): 38-45.

Jiménez, Onilda. “Un nuevo fenómeno de la literatura cubana; la novela policial”. Círculo: Publicación del Círculo de Cultura Panamericano 9 (1980): 93-100.

Nogueras, Luis Rogelio. Y si muero mañana. La Habana: Editorial Letras Cubanas, 1984. y Guillermo Rodríguez Rivera. “¿La verdadera novela policial?”. Por la novela policial. Luis Rogelio Nogueras, ed. La Habana: Editorial Arte y Literatura, 1982. 137-57.

López, Magdalena. "Vivir y escribir en Cuba. Desencanto y literatura. Entrevista a Leonardo Padura”. Iberoamericana VII/28 (2007): 163-167.

Ludmer, Josefina. "Ficciones cubanas en los últimos años: El problema de la literatura política”. Cuba: Un siglo de literatura (1902-2002). Anke Birkenmaier y Roberto González Echevarría, eds. Madrid: Editorial Colibrí, 2004. 357-73.

Padura Fuentes Leonardo. Adiós Hemingway. Barcelona: Tusquets Editores, 2006. “Novela policial y novela dela revolución”. Letras Cubanas (oct.-dic. 1988):55-89.

Ponte, Antonio José. La fiesta vigilada. Barcelona: Anagrama, 2007.

Portuondo, José Antonio. "En torno a la novela detectivesca”. Por la novela policial. Luis Rogelio Nogueras, ed. La Habana: Editorial Arte y Literatura, 1982. 33-79.

Quintero Herencia, Juan Carlos. “El espacio de la maldición: Escenográficas del Calibán de Roberto Fernández Retamar”. Roberto Fernández Retamar y los estudios latinoamericanos. Elzbieta Sklodowska y Ben A. Heller, eds. Pittsburgh: Instituto Internacional de Literatura Iberoamericana, 2000. 55-87.

Simpson, Amelia. Detective fiction from Latin America. London and Toronto: Associate University Press, 1990.

Todorov, Tzvetan. “The Typology of Detective Ficition”. Modern Criticism and Theory. David Lodge, ed. London: Longman, 1988. 157-65.

Uxo, Carlos. "Entrevista Con Leonardo Padura (Noviembre 2005)”. The Detective Fiction of Leonardo Padura Fuentes. Carlos Uxo, ed. Manchester: Manchester Metropolitan University Press, 2006. 27-53.

Wilkinson, Stephen. Detective Fiction in Cuban Society and Culture. Bern: Peter Lang, 2006.

\footnotetext{
Revista Iberoamericana, Vol. LXXVI, Núms. 232-233 Julio-Diciembre 2010, 671-693 
